\title{
PERUBAHAN PH SALIVA SISWA MA DARUL ISTIQAMAH MANADO SESUDAH MENYIKAT GIGI DENGAN PASTA GIGI MENGANDUNG XYLITOL
}

\author{
${ }^{1}$ Stevy B. Najoan \\ ${ }^{2}$ Billy J. Kepel \\ ${ }^{3}$ Dinar A. Wicaksono \\ ${ }^{1}$ Kandidat Skripsi Mahasiswa Program Studi Pendidikan Dokter Gigi Universitas Sam \\ Ratulangi Manado \\ ${ }^{2}$ Fakultas Kedokteran Universitas Sam Ratulangi Manado \\ ${ }^{3}$ Program Studi Pendidikan Dokter Gigi Universitas Sam Ratulangi Manado \\ Email: stvbastian@gmail.com
}

\begin{abstract}
Saliva plays a role in the occurrence of dental caries. The low of buffer capacity and secretion of saliva leads to reduced salivary ability in wash away food particles, deadly micro organisms and neutralize the salivary $\mathrm{pH}$. Changes in the salivary $\mathrm{pH}$ is influenced by circadian rhythms, the type of food consumed, stimulation of salivary secretion, salivary flow rate, micro organisms of the oral cavity and salivary buffer capacity. Xylitol is a sweetener similar to polyols that are non-acidogenic and non-cariogenic. Xylitolis difficult to be fermented by bacteria in the oral cavity so can help to increasing the decreases of salivary $\mathrm{pH}$ due the consumption of foods containing carbohydrates. In the field of dentistry, xylitol has been applied in a wide range of products such as chewing gums, lozenges, mouth washes and toothpastes. This study was conducted to determine the salivary $\mathrm{pH}$ before brushing teeth with tooth paste containing xylitol, the salivary pHafter brushing teeth with tooth paste containing xylitol and the changes of salivary $\mathrm{pH}$ after brushing teeth with tooth paste containing xylitol. The research design used was analytics experimental pretest and posttest design. The population used were 56 students of MA Darul Istiqamah Manado. Sampling was done by using simple random sampling technique with 20 samples were obtained by matched-pair research formula. Saliva collection methodsused werethe spittingmethod. The results showed a change in the salivary $\mathrm{pH}$ after brushing teeth with tooth paste containing xylitol. The average value ofthe salivary $\mathrm{pH}$ after brushing teeth with tooth paste containing xylitol were 7,18 higher than the average value of the salivary $\mathrm{pH}$ before brushing teeth with tooth paste containing xylitol were 6.99. Results of statistical tests of paired-samples t-test showed that there were significant differences $(p<0.05)$ of the salivary $\mathrm{pH}$ before and after brushing teeth with tooth paste containing xylitol. Conclution: Xylitol has a role in increasing the salivary $\mathrm{pH}$ which helps in inhibiting dental caries.
\end{abstract}

Keywords: salivary $\mathrm{pH}$, brushing teeth, toothpaste containing xylitol.

\begin{abstract}
Abstrak: Saliva berperan dalam proses terjadinya karies gigi. Rendahnya sekresi dan kapasitas bufer saliva menyebabkan berkurangnya kemampuan saliva dalam membersihkan sisa makanan, mematikan mikroorganisme serta menetralkan $\mathrm{pH}$ saliva. Perubahan $\mathrm{pH}$ saliva dipengaruhi oleh irama sirkadian, jenis makanan yang dikonsumsi, stimulasi sekresi saliva, laju aliran saliva, mikroorganisme rongga mulut dan kapasitas bufer saliva. Xylitol merupakan sejenis pemanis polyols yang bersifat nonasidogenik dan non-kariogenik. Xylitol sulit untuk difermentasi oleh bakteri dalam rongga mulut sehingga dapat membantu dalam meningkatkan $\mathrm{pH}$ saliva yang turun akibat konsumsi makanan yang mengandung karbohidrat. Dalam bidang kedokteran gigi, xylitol telah banyak diaplikasikan dalam berbagai macam produk seperti permen karet, tablet hisap, obat kumur dan pasta gigi. Penelitian ini dilakukan untuk mengetahui $\mathrm{pH}$ saliva sebelum menyikat gigi dengan pasta gigi mengandung xylitol, $\mathrm{pH}$ saliva sesudah menyikat gigi dengan pasta gigi mengandung xylitol dan perubahan $\mathrm{pH}$ saliva sesudah menyikat gigi dengan pasta gigi mengandung xylitol. Rancangan penelitian yang digunakan
\end{abstract}


yaitu analytic experimental pretest and posttest design. Populasi yang digunakan yaitu siswa MA Darul Istiqamah Manado yang berjumlah 56 orang. Pengambilan sampel dilakukan dengan teknik simple random sampling dengan jumlah sampel yang didapatkan yaitu 20 orang berdasarkan rumus penelitian dua populasi berpasangan. Metode pengumpulan saliva yang digunakan yaitu spitting method. Hasil penelitian menunjukkan terjadi perubahan $\mathrm{pH}$ saliva sesudah menyikat gigi dengan pasta gigi mengandung xylitol. Nilai rata-rata $\mathrm{pH}$ saliva sesudah menyikat gigi dengan pasta gigi mengandung xylitol yaitu 7,18 lebih tinggi dari nilai rata-rata $\mathrm{pH}$ saliva sebelum menyikat gigi dengan pasta gigi mengandung xylitol yaitu 6,99. Hasil uji statistik paired-samples t-test memperlihatkan bahwa terdapat perbedaan yang bermakna $(\mathrm{p}<0,05) \mathrm{pH}$ saliva sebelum dan sesudah menyikat gigi dengan pasta gigi mengandung xylitol. Simpulan: xylitol memiliki peran dalam meningkatkan $\mathrm{pH}$ saliva sehingga dapat mencegah terjadinya karies gigi.

Kata kunci: pH saliva, menyikat gigi, pasta gigi mengandung xylitol

Masalah kesehatan gigi dan mulut yang muncul di masyarakat, sangat bertolak belakang dengan banyaknya upaya kesehatan gigi dan mulut yang dilakukan untuk mencegahnya. Beragam informasi mengenai kesehatan gigi dan mulut yang mudah diperoleh melalui pemberitaan media dan upaya-upaya seperti penyuluhan dan skrining yang dilakukan masih belum mampu menangani masalah tersebut. Kesehatan gigi dan mulut masih dianggap sebagai masalah yang sepele bagi masyarakat.

Masalah kesehatan gigi dan mulut yang paling sering dialami masyarakat yaitu karies gigi atau lebih dikenal dengan istilah gigi berlubang. Karies gigi terjadi pada semua penduduk di dunia tanpa memandang strata sosial, golongan usia maupun jenis kelamin. Berdasarkan Riset Kesehatan Dasar (Riskesdas) tahun 2007 menunjukkan bahwa prevalensi karies penduduk Indonesia yaitu 43,4\% dengan indeks Decayed, Missing and Filled Teeth (DMF-T) sebesar 4,85. ${ }^{1}$ Hasil ini menunjukkan bahwa prevalensi karies gigi penduduk Indonesia masih tinggi.

Saliva berperan dalam proses terjadinya karies gigi. Rendahnya sekresi dan kapasitas bufer saliva menyebabkan berkurangnya kemampuan saliva dalam membersihkan sisa makanan, mematikan mikroorganisme serta menetralkan $\mathrm{pH}$ saliva. ${ }^{2}$ Aliran saliva dapat menurunkan akumulasi plak pada permukaan gigi dan menaikkan tingkat pembersihan karbohidrat dari rongga mulut. Selain itu, difusi kompenen saliva seperti kalsium dan fosfat ke dalam plak dapat menurunkan kelarutan email dan meningkat- kan remineralisasi gigi. Perubahan $\mathrm{pH}$ saliva dipengaruhi oleh irama sirkadian, jenis makanan yang dikonsumsi, stimulasi sekresi saliva, laju aliran saliva, mikroorganisme rongga mulut dan kapasitas bufer saliva. Konsumsi makanan yang mengandung karbohidrat akan dengan mudah difermentasi oleh bakteri seperti Streptococcus mutans. Proses fermentasi tersebut akan menghasilkan asam sehingga $\mathrm{pH}$ saliva menjadi turun. $^{3}$

Sukrosa sebagai pemanis makanan merupakan karbohidarat yang paling banyak dikonsumsi oleh masyarakat. Tingkat kariogenik dari sukrosa lebih tinggi dari jenis karbohdirat lainnya. Oleh karena itu, para peneliti mengembangkan bahan pemanis pengganti sukrosa yang bersifat nonkariogenik seperti gula alkohol yang salah satu di antaranya adalah xylitol. ${ }^{4}$

Xylitol merupakan sejenis pemanis polyols yang bersifat non-asidogenik dan non-kariogenik. ${ }^{5}$ Xylitol sulit untuk difermentasi oleh bakteri dalam rongga mulut sehingga dapat membantu dalam meningkatkan $\mathrm{pH}$ saliva yang turun akibat konsumsi makanan yang mengandung karbohidrat. ${ }^{6}$ Dalam bidang kedokteran gigi, xylitol telah banyak diaplikasikan dalam berbagai macam produk seperti permen karet, tablet hisap, obat kumur dan pasta gigi. ${ }^{5}$

Berdasarkan latar belakang di atas, penulis tertarik untuk melakukan penelitian tentang perubahan $\mathrm{pH}$ saliva sesudah menyikat gigi dengan pasta gigi mengandung xylitol. Penelitian ini dilakukan pada siswa Madrasah Aliyah (MA) Darul Istiqamah Manado. Sekolah ini terletak di 
Najoan, Kepel, Wicaksono; Perubahan pH Saliva Siswa MA Darul Istiqamah...

kelurahan Bailang kecamatan Bunaken kota Manado. Penelitian dilakukan di MA Darul Istiqamah Manado karena siswa-siswa di sekolah tersebut tinggal dalam lingkungan asrama sekolah. Dengan keadaan tersebut peneliti dapat mengoptimalkan efektivitas kerja dan efisiensi waktu selama penelitian.

Kisaran umur siswa di sekolah tersebut yaitu 15-18 tahun. Penelitian dilakukan pada kelompok umur ini karena gigi permanen sudah terekspos dengan lingkungan mulut selama 3-9 tahun. Oleh karena itu, menurut World Health Organization (WHO) penelitian pada kelompok umur ini dianggap lebih bermakna dibandingkan dengan kelompok umur lainnya. ${ }^{7}$

\section{METODE PENELITIAN}

Penelitian ini merupakan jenis penelitian eksperimental dengan rancangan penelitian yang digunakan yaitu analytic experimental pretest and posttest design. Penelitian ini dilaksanakan di MA Darul Istiqamah Manado pada bulan Januari April 2014. Populasi yang digunakan yaitu Siswa MA Darul Istiqamah Manado yang berjumlah 56 orang. Pengambilan sampel dilakukan dengan teknik simple random sampling dengan jumlah sampel yang didapatkan yaitu 20 orang berdasarkan rumus penelitian dua populasi berpasangan.

\section{HASIL PENELITIAN}

Siswa MA darul Istiqamah Manado berasal dari latar belakang yang berbeda baik dalam asal tempat tinggal, suku, etnis, status ekonomi dan kehidupan sosial, meskipun demikian kehidupan siswa bersifat homogen karena tinggal dalam satu lingkungan asrama. Berdasarkan jenis kelamin dari 20 orang yang diteliti menunjukkan bahwa subjek penelitian dengan jenis kelamin laki-laki sebanyak 10 orang (50\%) dan jenis kelamin perempuan sebanyak 10 orang (50\%) (Tabel 1).
Tabel 1. Distribusi subjek penelitian menurut jenis kelamin

\begin{tabular}{ccc}
\hline Jenis Kelamin & n & \% \\
\hline Laki-laki & 10 & 50 \\
Perempuan & 10 & 50 \\
Jumlah & 20 & 100 \\
\hline
\end{tabular}

Berdasarkan usia menunjukkan bahwa subjek penelitian yang berusia 15 tahun sebanyak 4 orang (20\%), yang berusia 16 tahun sebanyak 8 orang (40\%), yang berusia 17 tahun sebanyak 5 orang (25\%) dan yang berusia 18 tahun sebanyak 3 orang (15\%) (Tabel 2).

Tabel 2. Distribusi subjek penelitian menurut usia

\begin{tabular}{ccc}
\hline Usia & n & \% \\
\hline 15 & 4 & 20 \\
16 & 8 & 40 \\
17 & 5 & 25 \\
18 & 3 & 15 \\
Jumlah & 20 & 100 \\
\hline
\end{tabular}

Setelah 60 menit selesai makan, subjek penelitian diinstruksikan untuk mengumpulkan saliva awal ke dalam beaker glass. Saliva yang dikumpulkan kemudian diukur menggunakan alat $\mathrm{pH}$ meter Ezdo berskala 0-14 dengan sensitivitas $\pm 0,2$ yang sudah dikalibrasi sebelumnya. Subjek penelitian kemudian diberikan perlakuan yaitu dengan menyikat gigi menggunakan pasta gigi mengandung xylitol. Setelah 30 menit, subjek penelitian mengumpulkan saliva akhir pada beaker glass kemudian $\mathrm{pH}$ saliva diukur dengan alat $\mathrm{pH}$ meter.

Hasil pengukuran $\mathrm{pH}$ saliva yang dilakukan menunjukkan adanya perubahan $\mathrm{pH}$ saliva. Nilai rata-rata $\mathrm{pH}$ saliva sesudah menyikat gigi dengan pasta gigi mengandung xylitol yaitu 7,18 lebih tinggi dari nilai rata-rata $\mathrm{pH}$ saliva sebelum menyikat gigi dengan pasta gigi mengandung xylitol yaitu 6,99 (Tabel 3). 
Tabel 3. Hasil pengukuran $\mathrm{pH}$ saliva sebelum dan sesudah menyikat gigi dengan pasta gigi mengandung xylitol

\begin{tabular}{ccc}
\hline & \multicolumn{2}{c}{ pH saliva } \\
\hline & Sebelum & Sesudah \\
\hline Mean & 6,99 & 7,18 \\
Median & 7,00 & 7,20 \\
Modus & 6,70 & 7,20 \\
Max & 7,50 & 7,50 \\
Min & 6,60 & 6,80 \\
Range & 0,90 & 0,70 \\
SD & 0,26 & 0,18 \\
\hline
\end{tabular}

Pada hasil uji statistik paired-samples $t$ test didapatkan nilai rata-rata $\mathrm{pH}$ saliva sebelum menyikat gigi dengan pasta gigi mengandung xylitol yaitu 6,99 dengan standar deviasi 0,26. Nilai rata-rata $\mathrm{pH}$ saliva sesudah menyikat gigi dengan pasta gigi mengandung xylitol yaitu 7,18 dengan standar deviasi 0,18. Nilai signifikansi yang didapatkan yaitu 0,00 lebih kecil dari nilai probabilitas 0,05. Hasil tersebut menunjukkan terdapat perbedaan yang bermakna pada $\mathrm{pH}$ saliva sebelum dan sesudah menyikat gigi dengan pasta gigi mengandung xylitol (Tabel 4).

Tabel 4. Hasil uji statistik pH saliva sebelum dan sesudah menyikat gigi dengan pasta gigi mengandung xylitol

\begin{tabular}{ccccc}
\hline $\begin{array}{c}\mathrm{pH} \\
\text { saliva }\end{array}$ & $n$ & $\begin{array}{c}\text { Mea } \\
n\end{array}$ & $\begin{array}{c}\text { Std. } \\
\text { dev. }\end{array}$ & $\begin{array}{c}\text { Sig. (2- } \\
\text { tailed) }\end{array}$ \\
\hline Sebelum & 2 & 6,99 & 0,26 & \\
Sesudah & 0 & 7,18 & 0,18 & 0,00 \\
\hline
\end{tabular}

* Terdapat perbedaan yang bermakna $(\mathrm{p}<0,05)$

\section{BAHASAN}

Salah satu faktor penting yang dapat memengaruhi proses terjadinya demineralisasi pada permukaan gigi yaitu $\mathrm{pH}$ saliva. Perubahan $\mathrm{pH}$ saliva dipengaruhi oleh irama sirkadian, diet, stimulasi sekresi saliva, laju aliran saliva, mikroorganisme dan kapasitas bufer saliva. ${ }^{3,8,9}$ Dalam keadaan normal $\mathrm{pH}$ saliva berkisar antara 6,5-7,0. Makanan yang mengandung karbohidrat dapat difermentasi oleh bakteri plak sehingga menghasilkan asam yang dapat menurunkan $\mathrm{pH}$ saliva. ${ }^{10}$

Hasil penelitian yang dilakukan terhadap 20 siswa di MA Darul Istiqamah Manado menunjukkan bahwa terjadi perubahan $\mathrm{pH}$ saliva sesudah menyikat gigi dengan pasta gigi mengandung xylitol. Perubahan tersebut ditunjukkan dengan adanya peningkatan nilai rata-rata $\mathrm{pH}$ saliva sesudah menyikat gigi dengan pasta gigi mengandung xylitol (Tabel 3). Nilai rata-rata $\mathrm{pH}$ saliva sebelum menyikat gigi dengan pasta gigi mengandung xylitol yaitu 6,99 dengan standar deviasi 0,26 dan nilai rata-rata $\mathrm{pH}$ saliva sesudah menyikat gigi dengan pasta gigi mengandung xylitol yaitu 7,18 dengan standar deviasi 0,18. Nilai signifikansi yang didapatkan yaitu 0,00 lebih kecil dari nilai probabilitas 0,05. Hasil perhitungan tersebut menunjukkan bahwa terdapat perbedaan yang bermakna $\mathrm{pH}$ saliva sebelum dan sesudah menyikat gigi dengan pasta gigi mengandung xylitol (Tabel 4). Hasil penelitian ini sesuai dengan hasil penelitian yang dilakukan oleh Surdacka dimana terdapat perbedaan $\mathrm{pH}$ saliva sebelum dan sesudah menyikat gigi dengan pasta gigi yang mengandung xylitol. $^{11}$

Makanan yang mengandung karbohdirat yang diberikan berpengaruh terhadap perubahan $\mathrm{pH}$ saliva. Proses glikolisis yang berlangsung setelah subjek penelitian mengonsumsi makanan yang mengandung karbohidrat menyebabkan $\mathrm{pH}$ saliva menjadi turun. ${ }^{8}$ Pasokan substrat seperti karbohidrat akan difermentasi oleh bakteri di dalam rongga mulut sehingga menghasilkan asam organik berupa laktat, format dan piruvat yang dapat menurunkan $\mathrm{pH}$ saliva. ${ }^{2}$ Penurunan $\mathrm{pH}$ saliva yang terjadi tidak mencapai keadaan $\mathrm{pH}$ kritis saliva yaitu 4,5-5,5. ${ }^{3}$ Hal ini disebabkan karena kandungan bikarbonat, fosfat dan protein dalam saliva yang berperan dalam mempertahankan $\mathrm{pH}$ normal saliva. ${ }^{13}$

Perubahan $\mathrm{pH}$ saliva sesudah menyikat gigi dengan pasta gigi mengandung xylitol 
Najoan, Kepel, Wicaksono; Perubahan pH Saliva Siswa MA Darul Istiqamah...

ditunjukkan dengan adanya peningkatan $\mathrm{pH}$ saliva. Polyols seperti xylitol memiliki kemampuan untuk meningkatkan $\mathrm{pH}$ saliva yang turun akibat mengonsumsi makanan yang mengandung karbohidrat. ${ }^{14}$ Xylitol memiliki lima ikatan rantai karbon yang sulit untuk difermentasi oleh sebagian besar bakteri plak di dalam rongga mulut menjadi asam sehingga dapat mencegah terjadinya karies. $^{12,14}$

Pasta gigi mengandung xylitol dapat menghambat serta mempunyai efek anti bakteri terhadap pertumbuhan Streptococcus mutans serotipe E yang merupakan bakteri terbanyak di dalam rongga mulut. Semakin tinggi konsentrasi xylitol dalam pasta gigi maka semakin besar zona hambat terhadap bakteri. ${ }^{15}$ Pertumbuhan bakteri Streptococcus mutans dihambat dengan cara akumulasi xylitol 5-fosfat pada proses glikolisis. Daya hambat xylitol terhadap bakteri dalam mulut dilakukan berdasarkan reaksi metabolik. $^{16}$

Akumulasi xylitol yang memiliki lima ikatan rantai karbon dilakukan oleh bakteri rongga mulut yaitu dengan menggunakan sistem PTS (phosphotransferase system) sebagai mekanisme transportasi gula sehingga menghasilkan xylitol 5-fosfat. Xylitol 5-fosfat tidak dapat digunakan oleh bakteri rongga mulut dalam proses glikolisis sehingga dikembalikan ke lingkungan mulut. Dengan menempatkan bakteri dalam siklus energi sia-sia (futile energy cycle), xylitol dapat menghambat pertumbuhan bakteri dan meningkatkan $\mathrm{pH}$ saliva. ${ }^{16,17}$

Peningkatan $\mathrm{pH}$ saliva pada penelitian ini juga dipengaruhi oleh proses menyikat gigi. Adanya gerakan mekanis yaitu menyikat gigi dan berkumur dapat merangsang sekresi saliva. Meningkatnya sekresi saliva juga akan meningkatkan nilai $\mathrm{pH}$ saliva. Dengan adanya tambahan pasta gigi mengandung xylitol, maka perubahan $\mathrm{pH}$ saliva akan meningkat secara signifikan. ${ }^{18}$

Xylitol merupakan gula alkohol yang dapat dijadikan pengganti sukrosa sebagai bahan pemanis. Kelebihan xylitol dibandingkan dengan gula alkohol lainnya yaitu xylitol memiliki sifat non-asidogenik dan non-kariogenik. Efek xylitol terhadap perubahan $\mathrm{pH}$ saliva lebih signifikan dibandingkan sorbitol, laktitol dan manitol.,12 Xylitol juga memiliki efek terhadap kesehatan tubuh secara umum. Sifat xylitol yang sulit untuk diabsorpsi dapat mengurangi fluktuasi kadar gula dalam darah dan mampu untuk mengontrol kadar insulin dalam tubuh sehingga dapat digunakan dalam diet penderita diabetes. ${ }^{16}$ Kekurangan dari xylitol yaitu jika dikonsumsi dalam dosis yang tinggi akan mengganggu proses pencernaan. ${ }^{19}$

\section{SIMPULAN}

Terjadi perubahan $\mathrm{pH}$ saliva sesudah menyikat gigi dengan pasta gigi mengandung xylitol. Nilai rata-rata $\mathrm{pH}$ saliva sesudah menyikat gigi dengan pasta gigi mengandung xylitol yaitu 7,18 lebih tinggi dari nilai rata-rata $\mathrm{pH}$ saliva sebelum menyikat gigi dengan pasta gigi mengandung xylitol yaitu 6,99. Terdapat perbedaan yang bermakna $\mathrm{pH}$ saliva sebelum dan sesudah menyikat gigi dengan pasta gigi mengandung xylitol. Pasta gigi mengandung xylitol berperan dalam meningkatkan $\mathrm{pH}$ saliva sehingga dapat mencegah terjadinya karies gigi.

\section{SARAN}

Dianjurkan untuk menggunakan pasta gigi yang mengandung xylitol. Perlu dilakukan penelitian lebih lanjut mengenai perubahan $\mathrm{pH}$ saliva sebelum menyikat gigi, sesudah menyikat gigi dan sesudah menyikat gigi dengan pasta gigi mengandung xylitol.

\section{DAFTAR PUSTAKA}

1. Badan Penelitian dan Pengembangan Kesehatan. Riset kesehatan dasar (Riskesdas) 2007. Jakarta: Departemen Kesehatan Republik Indonesia. 2008. h. 130-40.

2. Prasetya RC. Perbandingan jumlah koloni bakteri saliva pada anak-anak karies dan non karies setelah mengkonsumsi minuman berkarbonasi. Indon J Dent. 2008; 15 (1). h. 65-70. 
3. Soesilo D, Santoso RE, Diyatri I. Peranan sorbitol dalam mempertahankan kestabilan $\mathrm{pH}$ saliva pada proses pencegahan karies. Maj Kedokt Gigi (Dent J), Vol. 38. No. 1. 2005. h. 25-8.

4. Pintauli S, Hamada T. Menuju gigi dan mulut sehat: pencegahan dan pemeliharaan. Ed. I. Medan: USU Press. 2008. h. 21.

5. Hiremath SS. Textbook of preventive and community dentistry. 2nd ed. New Delhi: Elsevier. 2011. p. 346.

6. Burt BA. The use of xylitol and sorbitol sweetened chewing gum in caries control. JADA, Vol. 132. 2006. p. 190-6.

7. World Health Organization. Oral health surveys: basic methods. 4th ed. Geneva: WHO Library Cataloguing in Publication Data. 1997. p. 7.

8. Amerongen AVN, Abyono R. Ludah dan kelenjar ludah: arti bagi kesehatan gigi. Yogyakarta: Gadjah Mada University Press. 1991. h. 18-20.

9. Rantonen P. Salivary flow and composition in healthy and disease adults. Helsinki: Helsinki University Central Hospital. 2003. p. 16.

10. Chernoff A. Geriatric nutrition: the health profesional's handbook. 3rd ed. Massachusetts: Jones and Bartlett Learning. 2006. p. 194.

11. Surdacka A, Stopa J. The effect of xylitol on the oral cavity environment. J Prevent Med. 2005; 13(1-2). p. 98-107.

12. Llop MR, Jimeno FG, Acien RM, Dalmau LJB. Effect of xylitol chewing gum on salivary flow rate, $\mathrm{pH}$, buffering capacity and presence of Streptococcus mutans in saliva. Eur J Paediatr Dent. 2011; 11(1). p. 9-14.

13. Kidd EAM, Bechal SJ. Dasar-dasar karies: penyakit dan penanggulangannya. Cetakan kedua. Jakarta : EGC. 1992. h. 66-78.

14. Walsh LJ. Dental plaque fermentation and its role in caries risk assessment. Int Dent SA. Vol. 8, No. 5 2006. p. 34-40.

15. Resti, Auerkari EI, Sarwono AT. Pengaruh pasta gigi mengandung xylitol terhadap pertumbuhan Streptococcus mutans serotipe E (in vitro). Indon J Dent. 2008; 15 (1). h. 15-22.

16. Holgersen PL. Xylitol and its effect on oral ecology - clinical studies in children and adolescents. Umea: Departemen of Odontology, Paediatric Dentistry, Faculty of Medicine Umea University. 2007. p.16-20.

17. Kauko K, Mäkinen. The rocky road of xylitol to its clinical application. J Dent Res. 79 (6). 2000. p. 1352-5.

18. Ligtenberg AJM, Brand HS, Bots CP, Amerongen AVN. The effect of tooth brushing on secretion rate, $\mathrm{pH}$ and buffering capacity of saliva. Int J Dent Hygiene. 2006. p. 104-5.

19. Pereira AFF, Silva TC, Silva TL, Caldana ML, Bastos JRM, Buzalaf MAR. Xylitol concentrations in artificial saliva after application of different xylitol dental varnishes. J Appl Oral Sci. 2012; 20(2). p. 146-50. 